\title{
Differential Genotoxicity of Diphenyl Diselenide (PhSe)2 and Diphenyl Ditelluride (PhTe)2
}

Organoselenium compounds have been pointed out as therapeutic agents. In contrast, the potential therapeutic aspects of tellurides have not yet been demonstrated. The present study evaluated the comparative toxicological effects of diphenyl diselenide (PhSe)2 and diphenyl ditelluride (PhTe)2 in mice after in vivo administration. Genotoxicity (as determined by comet assay) and mutagenicicity were used as end-points of toxicity. Subcutaneous administration of high doses of $(\mathrm{PhSe}) 2$ or $(\mathrm{PhTe}) 2(500 \mu \mathrm{mol} / \mathrm{Kg})$ caused distinct genotoxicity in mice. (PhSe)2 significantly decreased the DNA damage index after 48 and 96 hours of its injection $(p<0.05)$. In contrast, $(P h T e)$ caused a significant increase in DNA damage $(p<0.05)$ after 48 and 96 hours of intoxication. (PhSe)2 did not cause mutagenicity but (PhTe)2 increased the micronuclei frequency, indicating its mutagenic potential. The present study demonstrated that acute in vivo exposure to ditelluride caused genotoxicity in mice, which may be associated with pro-oxidant effects of diphenyl ditelluride. These results indicated that exposure to ditelluride can be genotoxic to mice and the use of this compound and possibly other related tellurides must be carefully controlled. 
1 Differential Genotoxicity of Diphenyl Diselenide $(\mathrm{PhSe})_{2}$ and Diphenyl Ditelluride (PhTe $)_{2}$

2

3

4

5

6

31 Universidade Federal de Santa Maria, 97105-900,

32 Santa Maria, RS, Brasil.

33 FAX: 55-55-32209462

Correspondence should be sent to:

* João B.T. da Rocha (PhD), jbtrocha@yahoo.com.br, and

* Waseem Hassan (PhD), waseem_anw@yahoo.com

\author{
Soares, Waseem Hassan * and João Batista T. Rocha*
}

Departamento de Bioquímica e Biologia Molecular, Centro de Ciências Naturais e Exatas, Universidade Federal de Santa Maria, Santa Maria, CEP 97105-900, RS, Brasil

Departamento de Química, Centro de Ciências Naturais e Exatas, 


\section{Abstract}

35 Organoselenium compounds have been pointed out as therapeutic agents. In contrast, the potential 36 therapeutic aspects of tellurides have not yet been demonstrated. The present study evaluated the 37 comparative toxicological effects of diphenyl diselenide $(\mathrm{PhSe})_{2}$ and diphenyl ditelluride $(\mathrm{PhTe})_{2}$ in mice 38 after in vivo administration. Genotoxicity (as determined by comet assay) and mutagenicicity were used 39 as end-points of toxicity. Subcutaneous administration of high doses of $(\mathrm{PhSe})_{2}$ or $(\mathrm{PhTe})_{2}(500 \mu \mathrm{mol} / \mathrm{Kg})$ 40 caused distinct genotoxicity in mice. $(\mathrm{PhSe})_{2}$ significantly decreased the DNA damage index after 48 and 4196 hours of its injection $(\mathrm{p}<0.05)$. In contrast, $(\mathrm{PhTe})$ caused a significant increase in DNA damage $42(\mathrm{p}<0.05)$ after 48 and 96 hours of intoxication. $(\mathrm{PhSe})_{2}$ did not cause mutagenicity but $(\mathrm{PhTe})_{2}$ increased 43 the micronuclei frequency, indicating its mutagenic potential. The present study demonstrated that acute in 44 vivo exposure to ditelluride caused genotoxicity in mice, which may be associated with pro-oxidant 45 effects of diphenyl ditelluride. These results indicated that exposure to ditelluride can be genotoxic to mice 46 and the use of this compound and possibly other related tellurides must be carefully controlled.

48 Keywords: Organotellurium, Organoselenium, Genotoxicity and Mutagenicity. 
Selenium (Se) and Tellurium (Te) belongs to the chalcogen family, sharing similar electronic configuration and some chemical properties with sulfur (S) (Comasseto et al., 1997; Comasseto, 2010). Se has a fundamental role in several living organisms as component of several antioxidant enzymes, including glutathione peroxidase and thioredoxin reductase (Arner et al., 2000; Nogueira \& Rocha., 2011). Despite its biological role, the excess of selenium can be toxic due its ability to generate free radicals and catalyze thiol oxidation (Barbosa et al., 1998; Nogueira, Zeni \& Rocha, 2004; Rocha et al., 2012; Hassan \& Rocha, 2012; Kade et al. 2013). The excess of free radical formation can damage mammalian tissues including thiol containing enzymes that are sensitive to pro-oxidant situations (Rocha et al., 2012 ; Rosa et al., 2007; Maciel et al., 2000). Diphenyl diselenide (PhSe) $)_{2}$ (Fig. 1) is a simple and stable organoselenium compound widely used in organic synthesis and it has been proposed as good candidate for pharmacological and therapeutic purposes (Nogueira, Zeni \& Rocha, 2004; Rosa et al. 2007; Nogueira \& Rocha, 2011). (PhSe) $)_{2}$ exhibits thiol peroxidase-like activity superior to that of ebselen, an organoselenium compound that has been used in clinical trial as antioxidant and mimetic of native glutathione peroxidase enzymes (Nogueira \& Rocha., 2011; Kade \& Rocha, 2013; Kade et al. 2013). However, exposure to high doses of $(\mathrm{PhSe})_{2}$ can deplete thiols in different tissues and can be neurotoxic to rodents (Maciel et al., 2000). The LD50 of diphenyl diselenide is $210 \mu \mathrm{mol} / \mathrm{kg}$ (intraperitoneal) or greater than $500 \mu \mathrm{mol} / \mathrm{kg}$ (subcutaneous) in adult mice (Nogueira et al. 2003).

There are reports that trace amounts of Te are present in body fluids such as blood and urine (Chasteen et al., 2009). Te has also been found in the form of tellurocysteine and telluromethionine in several proteins in bacteria, yeast and fungi but telluroproteins have not been identified in animal cells (Bienert et al., 2008). Thus, in contrast to selenium, tellurium does not have physiological functions (Taylor, 1996). Literature has demonstrated immunomodulatory, antioxidant and anticancer properties of various organotellurides (Nogueira, Zeni \& Rocha, 2004; Avila et al., 2012), semisynthetic tellurosubtilisin (Mao et al., 2005) and dendrimeric organotellurides (Francavilla et al., 2001). More sophisticated telluride molecules were synthesized from polystyrene nanoparticle via microemulsion polymerization. The nanoenzyme showed higher efficiency and provided a platform for the synthesis and designing of polymeric nanoparticles as excellent model of enzyme mimics (Huang et al., 2008). Organotellurium compounds can also mimic glutathione peroxidase activity (Engman et al., 1995) and, consequently, these compounds can be potential antioxidants, effective against hydrogen peroxide, peroxynitrite, hydroxyl radicals and superoxide anions (Anderssonet al., 1994; Kanski et al., 2001; Jacob et al., 2000). Recently, our research group demonstrated that organoselenium and organotellurium present hemolytic and genotoxic effects in human blood cells (Santos et al., 2009; Carean Bueno et al. 2013), which is in accordance with results published by other laboratories in experimental bacteria and rodent models

92 (Degrandi et al., 2010). Similarly,organoselenides and tellurides can be toxic in different in vivo and in 
93 vitro models of animal pathologies (Maciel et al., 2000; Taylor, 1996; Stangherlin et al., 2009; Moretto et 94 al., 2007; Heimfarth et al., 2011; Heimfarth et al., 2012 a; Heimfarth et al., 2012 b; Comparsi et al., 2012). 95 In effect, diphenyl ditelluride ( $\mathrm{PhTe})_{2}$ was found to be extremely toxic to mice and rats after acute or 96 chronic exposure (Maciel et al., 2000; Heimfarth et al., 2012 b ; Comparsi et al., 2012). The toxicity of 97 tellurides can be associated with their pro-oxidant activity, particularly, the oxidation of thiol- and selenol98 groups of proteins (Nogueira, Zeni \& Rocha, 2004; Comparsi et al. 2012; Hassan \& Rocha 2012).

99 Following our interest to determine the boundary between the potential protective and toxic properties of 100 organochalcogens, the present study was designed to evaluate the toxic potential of $(\mathrm{PhSe})_{2}$ and $(\mathrm{PhTe})_{2}$ in 101 in mice. We have determined the genotoxicity and mutagenicity of these compounds after acute 102 administration to Swiss male mice, using DNA damage and micronuclei frequency as end-points of 103 toxicity. 


\section{Chemicals}

106 The chemical structure of organochalcogens tested in this study is shown in (Figure I) diphenyl diselenide and (II) diphenyl ditelluride. The compounds were dissolved in canola oil immediately before use. $(\mathrm{PhSe})_{2}$ and $(\mathrm{PhTe})_{2}$ were obtained from Sigma-Aldrich. All other chemicals were of analytical grade and obtained from standard commercial suppliers.

\section{Animals}

111 Male Swiss adult mice weighing 30-40 g were obtained from our own breeding colony (Animal house-

112 holding, UFSM- Brazil). Animals were kept in separate animal cages, on a 12-h light/dark cycle, at a room 113 temperature of $\left(23^{\circ} \mathrm{C} \pm 3\right)$ and with free access to food and water. The animals were used according to the 114 guidelines of the committee on care and use of experimental animal resources of the Federal University Of 115 Santa Maria, Brazil (23081.002435/2007-16).

116 Mice were divided in six groups $(\mathrm{n}=5)$ and received one subcutaneous injection of (1) canola oil (Control 117 group 48h, mice were euthanized 48 hours after the oil injection); (2) diphenyl ditelluride (500 $\mu \mathrm{mol} / \mathrm{kg}$ in 118 canola oil, euthanized 48 hours after injection) ; (3) diphenyl diselenide (500 $\mu \mathrm{mol} / \mathrm{kg}$ in canola oil, 119 euthanized 48 hours after injection); (4) canola oil (Control group 96h, mice were euthanized 96 hours 120 after injection); (5) diphenyl ditelluride (500 $\mu \mathrm{mol} / \mathrm{kg}$ in canola oil, euthanized 96 hours after injection) 121 and (6) diphenyl diselenide (500 $\mu \mathrm{mol} / \mathrm{kg}$ in canola oil, euthanized 96 hours after injection). The doses 122 were based in a previous acute toxicological study by Maciel et al. 2000.

\section{Sample preparation for Comet Assay}

124 Mice were anesthesized with ketamine and $2.5 \mathrm{ml}$ blood samples were collected by heart puncture and 125 immediately euthanized by decaptation. Mice blood leukocytes were isolated and used in the comet test 126 but no pre-incubation was carried out (Santos et al. 2009(a); (b); Meinerz et al. 2011).

\section{Micronucleus test}

128 In micronucleus test (MN), two samples of blood from each animal were placed in a microscope slides 129 and air dried at room temperature. Slides were stained with 5\% May-Grunwald-Giemsa for 5 min. The 130 criteria used for the identification of $\mathrm{MN}$ were a size smaller than one-third of the main nucleus, no 131 attachment to the main nucleus, and identical color and intensity as in the main nucleus. MN were counted 132 in 2000 cells with well-preserved cytoplasm and calculated as: \% $\mathrm{MN}=$ number of cells containing 133 micronucleus X 100 / total number of cells counted. Micronuclei presence was determined by three 134 investigators that were blind to the animal treatments.

\section{Comet assay}

136 Comet assay is a rapid, simple and sensitive technique for measuring DNA breaks in single cells. This test 137 has been used to investigate the effect of many toxic agents on DNA (Collins et al., 2002; Blasiak et al., 138 2004). The comet assay was performed under alkaline conditions according to the procedures described by 
139 Santos et al. 2009 (a) and Santos et al., 2009 (b). The slides obtained from white cells of treated mice were

140 analyzed under blind conditions by at least two individuals. DNA damage is presented as DNA damage

141 index (DI). The DNA damage was calculated from cells in different damage classes (completely

142 undamaged: 100 cells $\times 0$ to maximum damaged -100 cells $\times 4$ ). Damage index is illustrated in Figure 2

143 and classes were determined considering the DNA tail and DNA migration length.

\section{Statistical analysis}

145 Data are expressed as mean \pm SD from 5 independent experiments performed in duplicate or triplicate.

146 Statistical analysis was performed using Kruskawallis test followed by Dun's test. Results were 147 considered statistically significant when $\mathrm{p}<0.05$.

148 
Results

150 No animal died during the experimental period. After 48 hours of diselenide or ditelluride treatment, mice

151 did not show symptoms of toxicity such as stereotypical behavior, ataxia, diarrhea, increased dieresis or 152 abdominal writings. However, after 96 hours, the group treated with $(\mathrm{PhTe})_{2}$ presented diarrhea, low level

153 of motor activity and a decrease in body weight (data not shown); which is in accordance with previous

154 finding from our laboratory (Maciel et al. 2000).

155

156 Comet assay

157 After in vivo administration, diphenyl diselenide caused a significant decrease in DNA damage index (DI)

158 both after 48 and 96 hours. In contrast, diphenyl ditelluride caused a significant increase in DNA damage 159 index (DI). After 48 hours, the damage caused by ditelluride was about 25 and $100 \%$ higher than control 160 and diphenyl diselenide groups, respectively (Table 1). After 96 hours, the DI caused by diphenyl 161 ditelluride was about 30 and 90\% higher than control and diselenide treated mice, respectively (Table 1).

162

163 Micronucleus test

164 After 48 or 96 hours of a single dose of diphenyl ditelluride, there was a significant increase in the number

165 of micronuclei in mice when compared with control and diphenyl diselenide group (Figure 3). Diphenyl

166 diselenide did not modify the number of micronuclei when compared to control group (Figure 3). 
169 The selected dose of both chalcogens was based on our previous report (Maciel et al., 2000), where we 170 tested different doses for acute and chronic exposure. Similarly, in the same dose range, diphenyl 171 diselenide has been reported to have interesting pharmacological effects, such as antinoception and anti172 inflammatory effects, among others, (see, for instance : Savegnago et al., 2008; Savegnago et al., 2007a; 173 Savegnago et al.,2007b and Savegnago et al.,2006). However, it must be emphasized here that in this 174 range of doses, it causes also toxicity in mice and rats (Nogueira et al. 2003; Nogueira and Rocha, 2011). 175 Consequently, the acute use of diphenyl diselenide may be possible, but its chronic or repeated use is 176 unfeasible.

177 The results presented here indicate clear toxic effects of $(\mathrm{PhTe})_{2}$ when compared with $(\mathrm{PhSe})_{2}$. Tellurium 178 (Te) has the potential of redox cycling which leads to formation of reactive oxygen species (ROS) which 179 can damage biomolecules (Maciel et al.,2000; Nogueira, Zeni \& Rocha, 2004; Santos et al., 2009; 180 Degrandi et al., 2010; Sailer et al., 2004; Caeran Bueno et al. 2013). Organotellurium-induced intracellular 181 ROS accumulation has been reported to be the cause of cell death in HL-60 and different types of cancer 182 cells (McNaughton et al., 2004; Juan et al., 2010; Ding et al.,2002; Rigobello et al., 2009). In contrast, 183 exposure of mice to $(\mathrm{PhSe})_{2}$ caused a significant decrease in the DNA damage index (DI) both after 48 184 and 96 hours of drug administration as shown in Table 1. The protective effect can be attributed to its anti185 oxidant or GPx like activity (Nogueira \& Rocha, 2011).

186 As observed in DNA damage test, the toxic behavior of $(\mathrm{PhTe})_{2}$ was completely different than $(\mathrm{PhSe})_{2}$ in 187 micronucleus assay. The frequency of mutations, showed by an increase of micronuclei frequency, 188 reinforce the toxicity of $(\mathrm{PhTe})_{2}$. It is important to note that $(\mathrm{PhSe})_{2}$ did not modify the number of 189 micronuclei, when compared to control group (Figure 3). Previous studies have also demonstrated 190 mutagenicicity of $(\mathrm{PhTe})_{2}$ at higher concentrations in V79 cells (Rosa et al., 2007). We have also reported 191 the mutagenicity of another Te-containing organic compound, (S)-dimethyl 2-(3-(phenyltellanyl) 192 propanamido) succinate in mice leucocytes (Meinerz et al., 2011

193 In conclusion, the results presented here indicate that diphenyl ditelluride is toxic to mice, whereas at the 194 same dose diphenyl diselenide had protective effects. These effects may be linked to the pro-oxidant 195 activity exhibited by organotellurium compounds. This data supports studies that have been published 196 about the toxicological and pharmacological effects of organochalcogens in different pathological models. 197 In effect, our data indicated that diphenyl diselenide can have protective effects after in vivo 198 administration to mice, which can be related to its antioxidant properties, whereas diphenyl ditelluride is much more toxic than diphenyl diselenide. Furthermore, in view of the genotoxic effect of $(\mathrm{PhTe})_{2}$, the indication in the literature that organotellurides could be therapeutically active compounds must be revisited taking into consideration the potential toxicity of this element. Accordingly, additional studies 
202 will be needed to elucidate the mechanism(s) by which $(\mathrm{PhTe})_{2}$ mediates its toxicity and whether or not 203 distinct chemical forms of organotellurides can have similar toxic effect in animal models. 
Andersson CM, Brattsand R, Hallberg A, Engman L, Persson J, Moldéus P, Cotgreave I, Diaryl tellurides

206 as inhibitors of lipid peroxidation in biological and chemical systems. Free Radic Res. 1994; 20: 401-410.

207 Arner ES, Holmgren P, Physiological functions of thioredoxin and thioredoxin reductase, European 208 Journal of Biochemistry. 2000; $267: 6102-6109$.

209 Avila DS, Benedetto A, Au C, Manarin F, Erikson K, Soares FA, Rocha JBT, Aschner M, Organotellurium 210 and organoselenium compounds attenuate Mn-induced toxicity in Caenorhabditis elegans by preventing 211 oxidative stress, Free Radical Biology and Medicine, 2012; 52: 1903-1910.

Barbosa NB, Rocha JBT, Zeni G, Emanuelli T, Beque MC, Braga AL, Effect of organic forms of selenium on - aminolevulinate dehydratase from liver, kidney, and brain of adult rats. Toxicology and Applied

214 Pharmacology. 1998; 149: 243-253.

215 Bienert GP, Schussler MD, Jahn TP, Metalloids: essential, beneficial or toxic? Major intrinsic proteins sort 216 it out. Trends Biochem. Sci., 2008; 33: 20-26.

Blasiak J, Arabski M, Krupa R, Basal, oxidative and alkalative DNA damage, DNA repair efficacy and mutagen ssensitivity in breast cancer. Mutation Research, 2004; 5224: 39-148.

Caeran Bueno D, Meinerz, DF, Allebrandt J, Waczuk EP, Dos Santos DB, Mariano DOC, Rocha JBT, Cytotoxicity and genotoxicity evaluation of organochalcogens in human leucocytes: A comparative study between ebselen, diphenyl diselenide, and diphenyl ditelluride. BioMed Res. Int., 2013, art. no. 537279

Chasteen TG, Fuentes DE, Tantalean TC, Vasquez CC, Tellurite: history, oxidative stress, and molecular mechanisms of resistance, FEMS Microbiol. Rev, 2009; 1-13.

Collins AR, Harrington V, Repair of oxidative DNA damage: assessing its contribution to cancer prevention. Mutagenisis, 2002; 17: 489-93.

Comasseto JV, Ling LW, Petragnani N, Stefani HA, Vinylic selenides and tellurides/preparation, reactivity and synthetic compounds. Synthesis 1997; 4: 373-403.

Comasseto, J. V. Selenium and tellurium chemistry: historical background. J Braz Chem Soc, 2010; 21, 2027-2031.

230 Comparsi B, Meinerz DF, Franco JL, Posser T, de Souza Prestes A, Stefanello ST, Dos Santos DB, 231 Wagner C, Farina M, Aschner M, Dafre AL, Rocha JB. Diphenyl ditelluride targets brain selenoproteins in 232 vivo: inhibition of cerebral thioredoxin reductase and glutathione peroxidase in mice after acute exposure.

233 Mol Cell Biochem. 2012; 370: 173-82.

234 Degrandi TH, De Oliveira IM, D'Almeida GM, Garcia CRL, Villela IV, Guecheva TN, Rosa RM, 235 Henriques JAP, Evaluation of the cytotoxicity, genotoxicity and mutagenicity of diphenyl ditelluride in 236 several biological models Mutagenesis, 2010; $25: 257-269$.

237 Ding DW, Hasegawa T, Peng D, Hosaka H, Seko Y, Preliminary investigation on the cytotoxicity of 238 tellurite to cultured HeLa cells. J Trace Elem Med Biol, 2002; 16: 99-102

239 Engman L, Person J, Vessman K, Ekstrom M, Berglund M, Andersson CM, Organotellurium compounds 240 as efficient retarders of lipid peroxidation in methanol. Free Radical Biology and Medicine, 1995; 9: 441241452.

242 Francavilla C, Drake MD, Bright FV, Detty MR, Dendrimeric Organochalcogen Catalysts for the

243 Activation of Hydrogen Peroxide: Improved Catalytic Activity through Statistical Effects and 244 Cooperativity in Successive Generations. J Am Chem Soc, 2001; 123: 57-67. 
245 Hassan W, Ibrahim M, Nogueira CW, Braga AL, Deobald AM, MohammadZai IU, Rocha JBT. Influence

246 of $\mathrm{pH}$ on the reactivity of diphenyl ditelluride with thiols and anti-oxidant potential in rat brain. Chemico-

247 Biological Interactions, 2009; 80: 47-53 (b)

248 Hassan W, Rocha JBT. Interaction profile of diphenyl diselenide with pharmacologically significant thiols.

249 Molecules. 2012; 19: 12287-96.

250 Heimfarth L, Loureiro SO, Reis KP, de Lima BO, Zamboni F, Gandolfi T, Narvaes R, da Rocha JBT, 251 Pessoa-Pureur R. Cross-talk among intracellular signaling pathways mediates the diphenyl ditelluride

252 actions on the hippocampal cytoskeleton of young rats. Chem Res Toxicol. 17, 2011; 24: 1754-64.

253

254

Heimfarth L, Loureiro SO, Dutra MF, Andrade C, Pettenuzzo L, Guma FT, Gonçalves CA, da Rocha JB, Pessoa-Pureur R. In vivo treatment with diphenyl ditelluride induces neurodegeneration in striatum of young rats: Implications of MAPK and Akt pathways. Toxicol Appl Pharmacol. 2012; 264 : 143-52 (b)

Heimfarth L, Loureiro SO, Reis KP, de Lima BO, Zamboni F, Lacerda S, Soska AK, Wild L, da Rocha JBT, Pessoa-Pureur R. Diphenyl ditelluride induces hypophosphorylation of intermediate filaments through modulation of DARPP-32-dependent pathways in cerebral cortex of young rats. Arch Toxicol.

259 2012; $86: 217-30$. (a)

260

261

262

263

264

265

266

267

268

269

270

271

272

273

274

275

276

277

278

279

280

281

282

283

284

285

Huang X, Liu Y, Liang K, Tang Y, Liu J, Construction of the active site of gluthathione peroxidase on polymer-based nanoparticles. Biomacromolecules, 2008; 9: 1467-1473.

Jacob C, Arteel GE, Kanda T, Engman L, Sies H, Water soluble organotellurium compounds: catalytic protection against peroxynitrite and release of zinc from metallothionein. Chem Res Toxicol, 2000; $13: 3-$ 9

Juan M, Sandoval, Philippe L, Bernard G, Claudio C, Vasquez PBC, Tellurite-induced oxidative stress leads to cell death of murine hepatocarcinoma cells. Biometals, 2010; 23: 623-632.

Kade, I. J., \& da Rocha, J. B. T. Pharmacology of organoselenium compounds: Emphasis on puzzling mechanistic switching from their glutathione peroxidase mimic in vivo. Biokemistri, 2013; 24, 1-14.

Kade, I. J., Balogun, B. D., \& Rocha, J. B. T. In Vitro Glutathione Peroxidase Mimcry of Ebselen is Linked to its Oxidation of Critical Thiols on Key Cerebral Suphydryl Proteins-A Novel Component of its GPx-mimic Antioxidant Mechanism Emerging from its Thiol-Modulated Toxicology and Pharmacology. Chemico-biological interactions. 2013

Kanski J, Drake J, Aksenova M, Engman L, Butterfield DA, Antioxidant activity of the organotellurium compound 3-[4-(N,N-dimethylamino) benzenetellurenyl] propanesulfonic acid against oxidative stress in synaptosomal membrane systems and neuronal cultures. Brain Res. 2001; 911 : 12-21.

Maciel EN, Bolzan RC, Braga AL, Rocha JBT, Diphenyl diselenide and diphenyl ditelluride differentially affect $\delta$-aminolevulinate dehydratase from liver, kidney, and brain of mice, Journal of Biochemical and Molecular Toxicology. 2000; 14: 310-319

Mao SZ, Dong ZY, Liu JQ, Li XQ, Liu XM, Luo GM, Shen JC, Semisynthethic tellurosubtilisin with gluthathione peroxidase activity. J Am Chem Soc, 2005; 127 : 11588-11589

McNaughton M, Engman L, Birmingham A, Powis G, Cotgreave IA, Cyclodextrin-derived diorganyl tellurides as glutathione peroxidase mimics and inhibitors of thioredoxin reductase and cancer cell growth. J Med Chem, 2004; 47: 233-239

Meinerz DF, Sudati JH, Santos DB, Frediani A, Alberto EE, Allebrandt J, Franco JL, Barbosa NBV, Aschner M, Rocha JBT, Evaluation of the biological effects of (S)-dimethyl 2-(3-(phenyltellanyl) 
propanamido) succinate, a new telluroamino acid derivative of aspartic acid. Achieves of Toxicology. 2011; 85 43-49

Mischell BB, Shiingi SM, Selected Methods in Cellular Immunology. W.H. Freeman Company, New York, pp. 1980; 1-469.

Moretto MB, Boff B, Franco J, Posser T, Roessler TM, Souza DO, Nogueira CW, Wofchuk S, Rocha JBT, $\mathrm{Ca}(2 \mathrm{p})$ influx in rat brain: effect of diorganylchalcogenides compounds. Toxicol. Sci., 2007; 99: 566-571.

Nogueira CW, Meotti FC, Curte E, Pilissão C, Zeni G, Rocha JBT. Investigations into the potential neurotoxicity induced by diselenides in mice and rats. Toxicology, 2003, 183: 29-37.

Nogueira CW, Rocha JBT, Toxicology and pharmacology of selenium: emphasis onsynthetic organoselenium compounds. Arch Toxicol. 2011; 85 : 1313-59.

Nogueira CW, Zen G, Rocha JBT, Organoselenium and organotellurium compounds: toxicology and pharmacology. Chem. Rev, 2004 104: 6255-6285.

Rigobello MP, Gandin V, Folda A, Rundlo AK, Fernandes FAP, Bindoli A, Marzano C, Bjornstedt M, Treatment of human cancer cells with selenite or tellurite in combination with auranofin enhances cell death due to redox shift. Free Radic Biol Med, 2009; 47: 710-721

Rocha JBT, Saraiva RA, Garcia SA, Gravina F, Nogueira CW, Aminolevulinate dehydratase ( $\delta$-ALA-D) as marker protein of intoxication with metals and other pro-oxidant situations. Toxicology Research,. 2012; 85-102

Rosa RM, Hoch NC, Furtado GV, Saffi J, Henriques JAP, DNA damage in tissues and organs of mice treated with diphenyl diselenide. Mutation Research. 2007; $633: 35-45$.

Sailer BL, Liles N, Dickerson S, Sumners S, Chasteen TG, Organotellurium compound toxicity in a promyelocytic cell line compared to non-tellurium-containing organic analogue. Toxicol In Vitro, 2004; $18: 475-482$

Santos DB, Schiar VPP, Paixão MW, Meinerz DF, Nogueira CW, Aschner M, Rocha JBT, Barbosa NBV, Hemolytic and genotoxic evaluation of organochalcogens in human blood cells in vitroToxicology in Vitro, 2009; 23: 1195-1204. (a)

Santos DB, Schiar VPP, Ribeiro MCP, Schwab RS, Meinerz DF, Allebrandt J, Rocha JBT, Nogueira CW, Aschner M, Barbosa NBV, Genotoxicity of organoselenium compounds in human leukocytes in vitro. Mutation Research, 2009; 676: 21-26. (b)

Savegnago L, Jesse CR, Pinto LG, Rocha JB, Nogueira CW. Diphenyl diselenide attenuates acute thermal hyperalgesia and persistent inflammatory and neuropathic pain behavior in mice. Brain Res. 2007; 1175: 54-9.

Savegnago L, Jesse CR, Santos AR, Rocha JB, Nogueira CW. Mechanisms involved in the antinociceptive effect caused by diphenyl diselenide in the formalin test. J Pharm Pharmacol. 2008; 60(12):1679-86.

Savegnago L, Pinto LG, Jesse CR, Rocha JB, Nogueira CW, Zeni G. Spinal mechanisms of antinociceptive action caused by diphenyl diselenide. Brain Res. 2007; 1162:32-7.

Savegnago L, Trevisan M, Alves D, Rocha JB, Nogueira CW, Zeni G. Antisecretory and antiulcer effects of diphenyl diselenide. Environ Toxicol Pharmacol. 2006; 21(1):86-92. 
325 Schiar VPP, Santos DB, Paixão MW, Nogueira CW, Rocha JBT, Zeni G, Human erythrocyte hemolysis 326 induced by selenium and tellurium compounds increased by GSH or glucose: a possible involvement of 327 reactive oxygen species. Chemico-Biological Interactions, 2009; 177: 28-33.

328 Stangherlin EC, Rocha JBT, Nogueira CW, Diphenyl ditelluride impairs short term memory and alters 329 neurochemical parameters in young rats. Pharmacol. Biochem. Behav, 2009; 91: 430-435.

330 Taylor,A. Biochemistry of Tellurium. Biological Trace Element Research, 1996; 55 : 231-239 


\section{Figure 1}

Structure of Diphenyl Diselenide and Diphenyl Ditelluride

Fig. 1 Structure of diphenyl diselenide and diphenyl ditelluride.
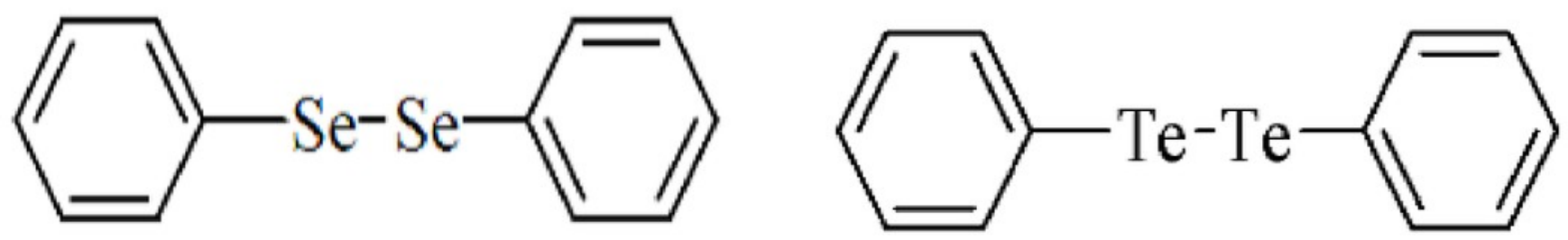


\section{Figure 2}

DNA damage quantification

Classifications of DNA damage in human leukocytes. DNA damage index was calculated from cells in different damage levels, which were classified in the visual score by the measurement of DNA migration length and in the amount of DNA in the tail. The level 5 was excluded of our evaluation. pared.

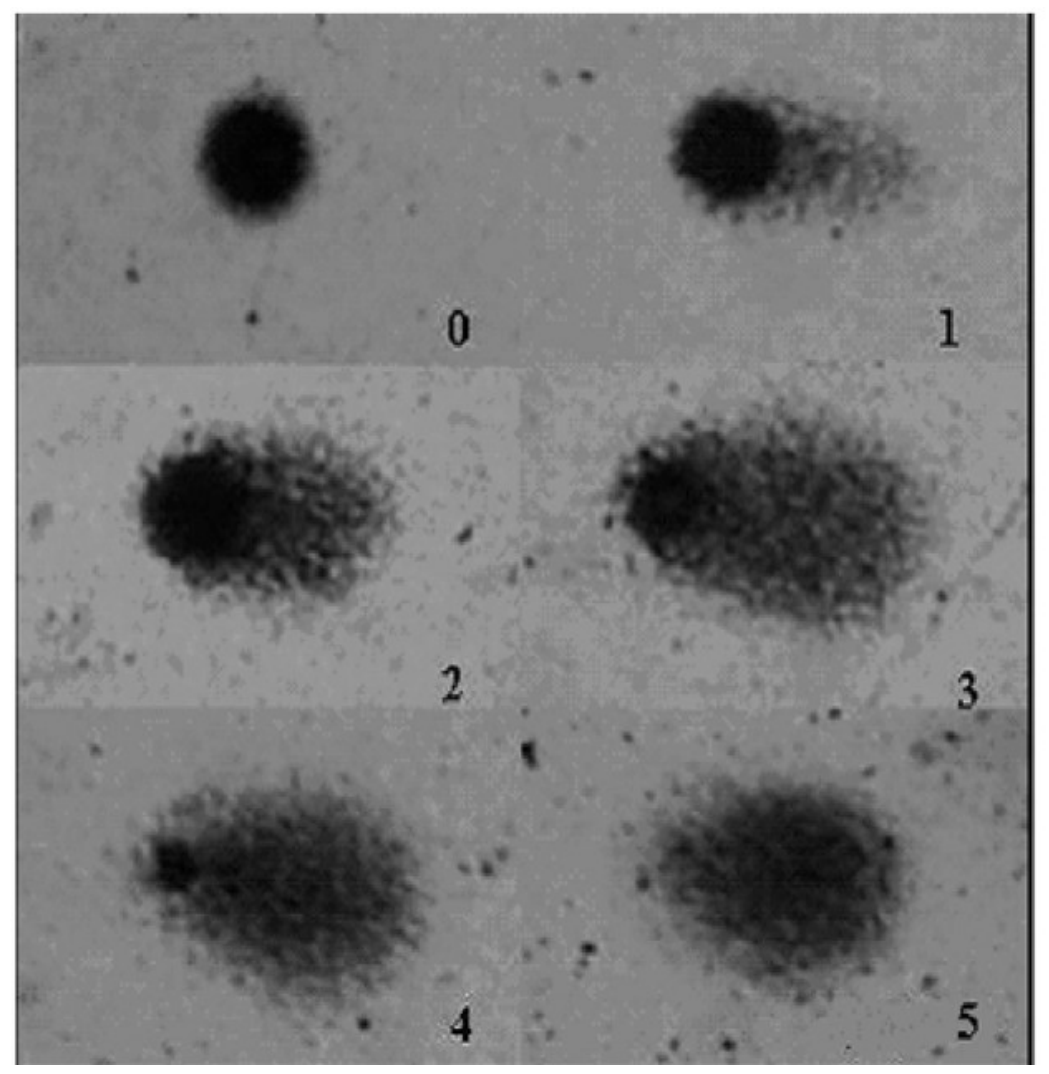




\section{Figure 3}

Micronuclei Frequency after Treatment with Diselenide and Ditelluride

Figure 3. Frequency of Micronuclei (MN) cells in mice exposed to (PhTe)2 or (PhSe)2. Mice were exposed to a sigle dose of diselenide or ditelluride (500 $\mu \mathrm{mol} / \mathrm{kg}$, s.c.). Forty eight and 96 hours after the injection, blood cells were examined for the presence of micronuclei. Data are expressed as mean $\pm S D$ for 5 mice per group. * Denoted $p>0.01$ as compared to control group; \# Denoted p > 0.01 as compared to diphenyl diselenide.

48 hours after treatment

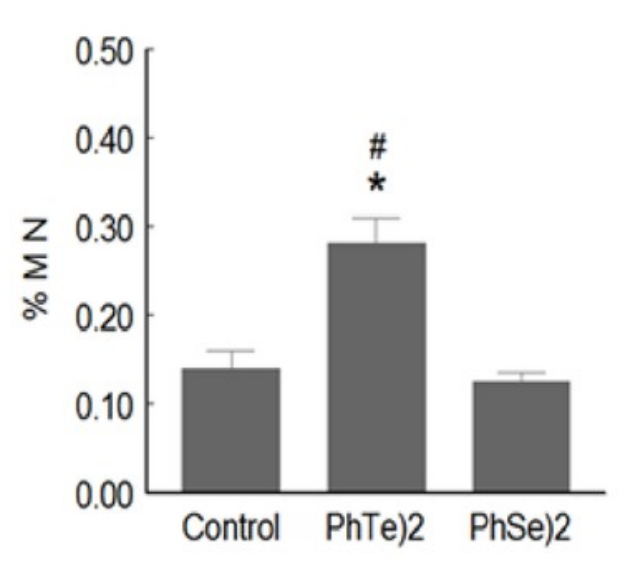

96 hours after treatment

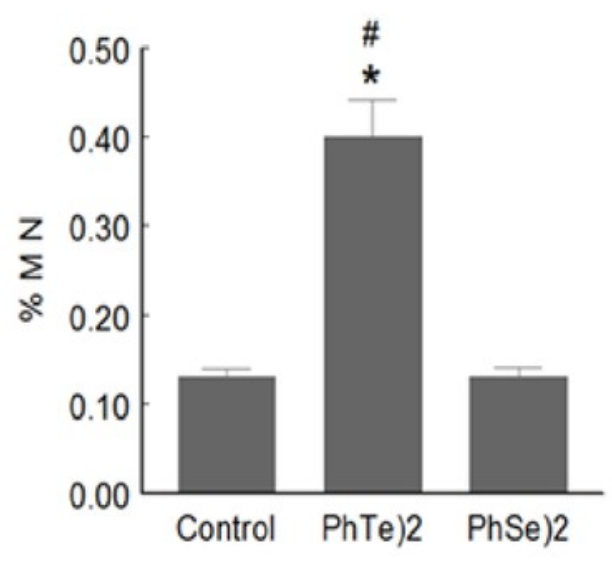




\section{Table 1 (on next page)}

DNA Damage Levels in Leucocytes from Mice Treated with Diselenide or Ditelluride

Table 1. Distribution of damage levels in mice leukocytes exposed to diphenyl diselenide and diphenyl ditelluride (500 $\mu \mathrm{mol} / \mathrm{kg}$, s.c.) DNA damage is presented as DNA damage index (DI). Data are expressed as means for five independent experiments. Statistical analysis by Kruskawalis test followed by Dun's test. 


\begin{tabular}{|c|c|c|c|c|c|c|c|}
\hline \multirow[t]{2}{*}{ Compound } & $\begin{array}{c}\text { Hours of } \\
\text { Exposition }\end{array}$ & \multicolumn{5}{|c|}{ Damage levels of DNA } & DI \\
\hline & & $\mathbf{0}$ & 1 & 2 & 3 & 4 & \\
\hline Control & $48 h$ & $61.0 \pm 0.5$ & $19.6 \pm 2.0$ & $13.4 \pm 1.4$ & $4.5 \pm 0.8$ & $1.0 \pm 0.5$ & $63.0 \pm 2.5^{\mathrm{a}}$ \\
\hline$(\mathrm{PhSe})_{2}$ & $48 \mathrm{~h}$ & $77.2 \pm 3.6$ & $11.8 \pm 1.6$ & $6.6 \pm 1.3$ & $3.8 \pm 1.1$ & $0.6 \pm 0.2$ & $40.8 \pm 7.8^{\mathrm{b}}$ \\
\hline$(\mathrm{PhTe})_{2}$ & $48 h$ & $48.0 \pm 9.7$ & $32.3 \pm 9.6$ & $13.0 \pm 3.2$ & $5.0 \pm 1.0$ & $1.6 \pm 0.6$ & $80.0 \pm 9.3^{\mathrm{c}}$ \\
\hline Control & $96 \mathrm{~h}$ & $63.5 \pm 0.5$ & $20.7 \pm 6.5$ & $12.5 \pm 5.5$ & $3.7 \pm 0.5$ & $0.0 \pm 0.0$ & $58.0 \pm 4.6^{\mathrm{a}}$ \\
\hline$(\mathrm{PhSe})_{2}$ & $96 h$ & $80.0 \pm 2.0$ & $10.0 \pm 2.0$ & $5.0 \pm 3.0$ & $3.0 \pm 0.6$ & $2.0 \pm 2.0$ & $40.0 \pm 1.1^{\mathrm{b}}$ \\
\hline$(\mathrm{PhTe})_{2}$ & $96 h$ & $59.5 \pm 3.5$ & $19.0 \pm 7.0$ & $12.0 \pm 3.0$ & $9.2 \pm 0.8$ & $1.6 \pm 0.5$ & $76.0 \pm 1.2^{\mathrm{c}}$ \\
\hline
\end{tabular}

1 Table 1. Distribution of damage levels in mice leukocytes exposed to diphenyl diselenide and diphenyl 2 ditelluride $(500 \mu \mathrm{mol} / \mathrm{kg}$, s.c. $)$

3.

4 DNA damage is presented as DNA damage index (DI). Data are expressed as means for five independent 5 experiments. Statistical analysis by Kruskawalis test followed by Dun's test. 


\section{Differential Genotoxicity of Diphenyl Diselenide $\left(\mathrm{PhSe}_{2}\right.$ and Diphenyl Ditelluride (PhTe)}

Daiane Francine Meinerz, Josiane Allebrandt, Douglas O. C. Mariano, Emily P. Waczuk, Felix Antunes Soares, Waseem Hassan * and João Batista T. Rocha*

Departamento de Bioquímica e Biologia Molecular, Centro de Ciências Naturais e Exatas, Universidade Federal de Santa Maria, Santa Maria, CEP 97105-900, RS, Brasil

Correspondence should be sent to:

* João B.T. da Rocha (PhD), jbtrocha@yahoo.com.br, and

* Waseem Hassan (PhD), waseem_anw@yahoo.com

Departamento de Química, Centro de Ciências Naturais e Exatas,

Universidade Federal de Santa Maria, 97105-900,

Santa Maria, RS, Brasil.

FAX: 55-55-32209462 


\begin{abstract}
Organoselenium compounds have been pointed out as therapeutic agents. In contrast, the potential therapeutic aspects of tellurides have not yet been demonstrated. The present study evaluated the comparative toxicological effects of diphenyl diselenide $(\mathrm{PhSe})_{2}$ and diphenyl ditelluride $(\mathrm{PhTe})_{2}$ in mice after in vivo administration. Genotoxicity (as determined by comet assay) and mutagenicicity were used as end-points of toxicity. Subcutaneous administration of high doses of $(\mathrm{PhSe})_{2}$ or $(\mathrm{PhTe})_{2}(500 \mu \mathrm{mol} / \mathrm{Kg})$ caused distinct genotoxicity in mice. $(\mathrm{PhSe})_{2}$ significantly decreased the DNA damage index after 48 and 96 hours of its injection $(\mathrm{p}<0.05)$. In contrast, $(\mathrm{PhTe})$ caused a significant increase in DNA damage $(\mathrm{p}<0.05)$ after 48 and 96 hours of intoxication. $(\mathrm{PhSe})_{2}$ did not cause mutagenicity but $(\mathrm{PhTe})_{2}$ increased the micronuclei frequency, indicating its mutagenic potential. The present study demonstrated that acute in vivo exposure to ditelluride caused genotoxicity in mice, which may be associated with pro-oxidant effects of diphenyl ditelluride. These results indicated that exposure to ditelluride can be genotoxic to mice and the use of this compound and possibly other related tellurides must be carefully controlled.
\end{abstract}

Keywords: Organotellurium, Organoselenium, Genotoxicity and Mutagenicity. 


\section{Introduction}

Selenium (Se) and Tellurium (Te) belongs to the chalcogen family, sharing similar electronic configuration and some chemical properties with sulfur (S) (Comasseto et al., 1997; Comasseto, 2010). Se has a fundamental role in several living organisms as component of several antioxidant enzymes, including glutathione peroxidase and thioredoxin reductase (Arner et al., 2000; Nogueira \& Rocha., 2011). Despite its biological role, the excess of selenium can be toxic due its ability to generate free radicals and catalyze thiol oxidation (Barbosa et al., 1998; Nogueira, Zeni \& Rocha, 2004; Rocha et al., 2012; Hassan \& Rocha, 2012; Kade et al. 2013). The excess of free radical formation can damage mammalian tissues including thiol containing enzymes that are sensitive to pro-oxidant situations (Rocha et al., 2012 ; Rosa et al., 2007; Maciel et al., 2000). Diphenyl diselenide (PhSe) $)_{2}$, Fig. 1) is a simple and stable organoselenium compound widely used in organic synthesis and it has been proposed as good candidate for pharmacological and therapeutic purposes (Nogueira, Zeni \& Rocha, 2004; Rosa et al. 2007; Nogueira \& Rocha, 2011). (PhSe) $)_{2}$ exhibits thiol peroxidase-like activity superior to that of ebselen, an organoselenium compound that has been used in clinical trial as antioxidant and mimetic of native glutathione peroxidase enzymes (Nogueira \& Rocha., 2011; Kade \& Rocha, 2013; Kade et al. 2013). However, exposure to high doses of $(\mathrm{PhSe})_{2}$ can deplete thiols in different tissues and can be neurotoxic to rodents (Maciel et al., 2000). The LD50 of diphenyl diselenide is $210 \mu \mathrm{mol} / \mathrm{kg}$ (intraperitoneal) or greater than $500 \mu \mathrm{mol} / \mathrm{kg}$ (subcutaneous) in adult mice (Nogueira et al. 2003).

There are reports that trace amounts of Te are present in body fluids such as blood and urine (Chasteen et al., 2009). Te has also been found in the form of tellurocysteine and telluromethionine in several proteins in bacteria, yeast and fungi but telluroproteins have not been identified in animal cells (Bienert et al., 2008). Thus, in contrast to selenium, tellurium does not have physiological functions (Taylor, 1996). Literature has demonstrated immunomodulatory, antioxidant and anticancer properties of various organotellurides (Nogueira, Zeni \& Rocha, 2004; Avila et al., 2012), semisynthetic tellurosubtilisin (Mao et al., 2005) and dendrimeric organotellurides (Francavilla et al., 2001). More sophisticated telluride molecules were synthesized from polystyrene nanoparticle via microemulsion polymerization. The nanoenzyme showed higher efficiency and provided a platform for the synthesis and designing of polymeric nanoparticles as excellent model of enzyme mimics (Huang et al., 2008). Organotellurium compounds can also mimic glutathione peroxidase activity (Engman et al., 1995) and, consequently, these compounds can be potential antioxidants, effective against hydrogen peroxide, peroxynitrite, hydroxyl radicals and superoxide anions (Anderssonet al., 1994; Kanski et al., 2001; Jacob et al., 2000).

Recently, our research group demonstrated that organoselenium and organotellurium present hemolytic and genotoxic effects in human blood cells (Santos et al., 2009; Carean Bueno et al. 2013), which is in 
accordance with results published by other laboratories in experimental bacteria and rodent models (Degrandi et al., 2010). Similarly,organoselenides and tellurides can be toxic in different in vivo and in vitro models of animal pathologies (Maciel et al., 2000; Taylor, 1996; Stangherlin et al., 2009; Moretto et al., 2007; Heimfarth et al., 2011; Heimfarth et al., 2012 a; Heimfarth et al., 2012 b; Comparsi et al., 2012). In effect, diphenyl ditelluride ( $\mathrm{PhTe})_{2}$ was found to be extremely toxic to mice and rats after acute or chronic exposure (Maciel et al., 2000; Heimfarth et al., 2012 b ; Comparsi et al., 2012). The toxicity of tellurides can be associated with their pro-oxidant activity, particularly, the oxidation of thiol- and selenol-groups of proteins (Nogueira, Zeni \& Rocha, 2004; Comparsi et al. 2012; Hassan \& Rocha 2012). Following our interest to determine the boundary between the potential protective and toxic properties of organochalcogens, the present study was designed to evaluate the toxic potential of $(\mathrm{PhSe})_{2}$ and $(\mathrm{PhTe})_{2}$ in in mice. We have determined the genotoxicity and mutagenicity of these compounds after acute administration to Swiss male mice, using DNA damage and micronuclei frequency as end-points of toxicity. 


\section{Material and Methods}

\section{Chemicals}

The chemical structure of organochalcogens tested in this study is shown in (Figure I) diphenyl diselenide and (II) diphenyl ditelluride. The compounds were dissolved in canola oil immediately before use. $(\mathrm{PhSe})_{2}$ and $(\mathrm{PhTe})_{2}$ were obtained from Sigma-Aldrich. All other chemicals were of analytical grade and obtained from standard commercial suppliers.

\section{Animals}

Male Swiss adult mice weighing 30-40 g were obtained from our own breeding colony (Animal householding, UFSM- Brazil). Animals were kept in separate animal cages, on a 12-h light/dark cycle, at a room temperature of $\left(23^{\circ} \mathrm{C} \pm 3\right)$ and with free access to food and water. The animals were used according to the guidelines of the committee on care and use of experimental animal resources of the Federal University Of Santa Maria, Brazil (23081.002435/2007-16).

Mice were divided in six groups $(\mathrm{n}=5)$ and received one subcutaneous injection of (1) canola oil (Control group 48h, mice were euthanized 48 hours after the oil injection); (2) diphenyl ditelluride (500 $\mu \mathrm{mol} / \mathrm{kg}$ in canola oil, euthanized 48 hours after injection) ; (3) diphenyl diselenide (500 $\mu \mathrm{mol} / \mathrm{kg}$ in canola oil, euthanized 48 hours after injection); (4) canola oil (Control group 96h, mice were euthanized 96 hours after injection); (5) diphenyl ditelluride (500 $\mu \mathrm{mol} / \mathrm{kg}$ in canola oil, euthanized 96 hours after injection) and (6) diphenyl diselenide (500 $\mu \mathrm{mol} / \mathrm{kg}$ in canola oil, euthanized 96 hours after injection). The doses were based in a previous acute toxicological study by Maciel et al. 2000.

\section{Sample preparation for Comet Assay}

Mice were anesthesized with ketamine and $2.5 \mathrm{ml}$ blood samples were collected by heart puncture and immediately euthanized by decaptation. Mice blood leukocytes were isolated and used in the comet test but no pre-incubation was carried out (Santos et al. 2009(a); (b); Meinerz et al. 2011).

\section{Micronucleus test}

In micronucleus test (MN), two samples of blood from each animal were placed in a microscope slides and air dried at room temperature. Slides were stained with 5\% May-Grunwald-Giemsa for 5 min. The criteria used for the identification of $\mathrm{MN}$ were a size smaller than one-third of the main nucleus, no attachment to the main nucleus, and identical color and intensity as in the main nucleus. MN were counted in 2000 cells with well-preserved cytoplasm and calculated as: \% $\mathrm{MN}=$ number of cells containing micronucleus X 100 / total number of cells counted. Micronuclei presence was determined by three investigators that were blind to the animal treatments.

\section{Comet assay}

Comet assay is a rapid, simple and sensitive technique for measuring DNA breaks in single cells. This test has been used to investigate the effect of many toxic agents on DNA (Collins et al., 2002; Blasiak et al., 
2004). The comet assay was performed under alkaline conditions according to the procedures described by Santos et al. 2009 (a) and Santos et al., 2009 (b). The slides obtained from white cells of treated mice were analyzed under blind conditions by at least two individuals. DNA damage is presented as DNA damage index (DI). The DNA damage was calculated from cells in different damage classes (completely undamaged: 100 cells $\times 0$ to maximum damaged -100 cells $\times 4$ ). Damage index is illustrated in Figure 2 and classes were determined considering the DNA tail and DNA migration length.

\section{Statistical analysis}

Data are expressed as mean \pm SD from 5 independent experiments performed in duplicate or triplicate. Statistical analysis was performed using Kruskawallis test followed by Dun's test. Results were considered statistically significant when $\mathrm{p}<0.05$. 


\section{Results}

No animal died during the experimental period. After 48 hours of diselenide or ditelluride treatment, mice did not show symptoms of toxicity such as stereotypical behavior, ataxia, diarrhea, increased dieresis or abdominal writings. However, after 96 hours, the group treated with $(\mathrm{PhTe})_{2}$ presented diarrhea, low level of motor activity and a decrease in body weight (data not shown); which is in accordance with previous finding from our laboratory (Maciel et al. 2000).

\section{Comet assay}

After in vivo administration, diphenyl diselenide caused a significant decrease in DNA damage index (DI) both after 48 and 96 hours. In contrast, diphenyl ditelluride caused a significant increase in DNA damage index (DI). After 48 hours, the damage caused by ditelluride was about 25 and $100 \%$ higher than control and diphenyl diselenide groups, respectively (Table 1). After 96 hours, the DI caused by diphenyl ditelluride was about 30 and 90\% higher than control and diselenide treated mice, respectively (Table 1).

\section{Micronucleus test}

After 48 or 96 hours of a single dose of diphenyl ditelluride, there was a significant increase in the number of micronuclei in mice when compared with control and diphenyl diselenide group (Figure 3). Diphenyl diselenide did not modify the number of micronuclei when compared to control group (Figure $3)$. 


\section{Discussion}

The selected dose of both chalcogens was based on our previous report (Maciel et al., 2000), where we tested different doses for acute and chronic exposure. Similarly, in the same dose range, diphenyl diselenide has been reported to have interesting pharmacological effects, such as antinoception and antiinflammatory effects, among others, (see, for instance : Savegnago et al., 2008; Savegnago et al., 2007a; Savegnago et al.,2007b and Savegnago et al.,2006). However, it must be emphasized here that in this range of doses, it causes also toxicity in mice and rats (Nogueira et al. 2003; Nogueira and Rocha, 2011). Consequently, the acute use of diphenyl diselenide may be possible, but its chronic or repeated use is unfeasible.

The results presented here indicate clear toxic effects of $(\mathrm{PhTe})_{2}$ when compared with $(\mathrm{PhSe})_{2}$. Tellurium (Te) has the potential of redox cycling which leads to formation of reactive oxygen species (ROS) which can damage biomolecules (Maciel et al.,2000; Nogueira, Zeni \& Rocha, 2004; Santos et al., 2009; Degrandi et al., 2010; Sailer et al., 2004; Caeran Bueno et al. 2013). Organotellurium-induced intracellular ROS accumulation has been reported to be the cause of cell death in HL-60 and different types of cancer cells (McNaughton et al., 2004; Juan et al., 2010; Ding et al.,2002; Rigobello et al., 2009). In contrast, exposure of mice to $(\mathrm{PhSe})_{2}$ caused a significant decrease in the DNA damage index (DI) both after 48 and 96 hours of drug administration as shown in Table 1 . The protective effect can be attributed to its anti-oxidant or GPx like activity (Nogueira \& Rocha, 2011).

As observed in DNA damage test, the toxic behavior of $(\mathrm{PhTe})_{2}$ was completely different than $(\mathrm{PhSe})_{2}$ in micronucleus assay. The frequency of mutations, showed by an increase of micronuclei frequency, reinforce the toxicity of $(\mathrm{PhTe})_{2}$. It is important to note that $(\mathrm{PhSe})_{2}$ did not modify the number of micronuclei, when compared to control group (Figure 3). Previous studies have also demonstrated mutagenicicity of (PhTe) $)_{2}$ at higher concentrations in V79 cells (Rosa et al., 2007). We have also reported the mutagenicity of another Te-containing organic compound, (S)-dimethyl 2-(3-(phenyltellanyl) propanamido) succinate in mice leucocytes (Meinerz et al., 2011

In conclusion, the results presented here indicate that diphenyl ditelluride is toxic to mice, whereas at the same dose diphenyl diselenide had protective effects. These effects may be linked to the pro-oxidant activity exhibited by organotellurium compounds. This data supports studies that have been published about the toxicological and pharmacological effects of organochalcogens in different pathological models. In effect, our data indicated that diphenyl diselenide can have protective effects after in vivo administration to mice, which can be related to its antioxidant properties, whereas diphenyl ditelluride is much more toxic than diphenyl diselenide. Furthermore, in view of the genotoxic effect of $(\mathrm{PhTe})_{2}$, the indication in the literature that organotellurides could be therapeutically active compounds must be revisited taking into consideration the potential toxicity of this element. Accordingly, additional studies 
will be needed to elucidate the mechanism(s) by which $(\mathrm{PhTe})_{2}$ mediates its toxicity and whether or not distinct chemical forms of organotellurides can have similar toxic effect in animal models. 


\section{Reference;}

Andersson CM, Brattsand R, Hallberg A, Engman L, Persson J, Moldéus P, Cotgreave I, Diaryl tellurides as inhibitors of lipid peroxidation in biological and chemical systems. Free Radic Res. 1994; 20: 401410.

Arner ES, Holmgren P, Physiological functions of thioredoxin and thioredoxin reductase, European Journal of Biochemistry. 2000; 267 : 6102-6109.

Avila DS, Benedetto A, Au C, Manarin F, Erikson K, Soares FA, Rocha JBT, Aschner M, Organotellurium and organoselenium compounds attenuate $\mathrm{Mn}$-induced toxicity in Caenorhabditis elegans by preventing oxidative stress, Free Radical Biology and Medicine, 2012; 52: 1903-1910.

Barbosa NB, Rocha JBT, Zeni G, Emanuelli T, Beque MC, Braga AL, Effect of organic forms of selenium on - aminolevulinate dehydratase from liver, kidney, and brain of adult rats. Toxicology and Applied Pharmacology. 1998; 149: 243-253.

Bienert GP, Schussler MD, Jahn TP, Metalloids: essential, beneficial or toxic? Major intrinsic proteins sort it out. Trends Biochem. Sci., 2008; 33: 20-26.

Blasiak J, Arabski M, Krupa R, Basal, oxidative and alkalative DNA damage, DNA repair efficacy and mutagen ssensitivity in breast cancer. Mutation Research, 2004; 5224: 39-148.

Caeran Bueno D, Meinerz, DF, Allebrandt J, Waczuk EP, Dos Santos DB, Mariano DOC, Rocha JBT, Cytotoxicity and genotoxicity evaluation of organochalcogens in human leucocytes: A comparative study between ebselen, diphenyl diselenide, and diphenyl ditelluride. BioMed Res. Int., 2013, art. no. 537279

Chasteen TG, Fuentes DE, Tantalean TC, Vasquez CC, Tellurite: history, oxidative stress, and molecular mechanisms of resistance, FEMS Microbiol. Rev, 2009; 1-13.

Collins AR, Harrington V, Repair of oxidative DNA damage: assessing its contribution to cancer prevention. Mutagenisis, 2002; 17: 489-93.

Comasseto JV, Ling LW, Petragnani N, Stefani HA, Vinylic selenides and tellurides/preparation, reactivity and synthetic compounds. Synthesis 1997; 4: 373-403.

Comasseto, J. V. Selenium and tellurium chemistry: historical background. J Braz Chem Soc, 2010; 21, 2027-2031.

Comparsi B, Meinerz DF, Franco JL, Posser T, de Souza Prestes A, Stefanello ST, Dos Santos DB, Wagner C, Farina M, Aschner M, Dafre AL, Rocha JB. Diphenyl ditelluride targets brain selenoproteins in vivo: inhibition of cerebral thioredoxin reductase and glutathione peroxidase in mice after acute exposure. Mol Cell Biochem. 2012; 370: 173-82.

Degrandi TH, De Oliveira IM, D'Almeida GM, Garcia CRL, Villela IV, Guecheva TN, Rosa RM, Henriques JAP, Evaluation of the cytotoxicity, genotoxicity and mutagenicity of diphenyl ditelluride in several biological models Mutagenesis, 2010; $25: 257-269$.

Ding DW, Hasegawa T, Peng D, Hosaka H, Seko Y, Preliminary investigation on the cytotoxicity of tellurite to cultured HeLa cells. J Trace Elem Med Biol, 2002; 16: 99-102

Engman L, Person J, Vessman K, Ekstrom M, Berglund M, Andersson CM, Organotellurium compounds as efficient retarders of lipid peroxidation in methanol. Free Radical Biology and Medicine, 1995; 9: 441452. 
Francavilla C, Drake MD, Bright FV, Detty MR, Dendrimeric Organochalcogen Catalysts for the Activation of Hydrogen Peroxide: Improved Catalytic Activity through Statistical Effects and Cooperativity in Successive Generations. J Am Chem Soc, 2001; 123: 57-67.

Hassan W, Ibrahim M, Nogueira CW, Braga AL, Deobald AM, MohammadZai IU, Rocha JBT. Influence of $\mathrm{pH}$ on the reactivity of diphenyl ditelluride with thiols and anti-oxidant potential in rat brain. ChemicoBiological Interactions, 2009; 80: 47-53 (b)

Hassan W, Rocha JBT. Interaction profile of diphenyl diselenide with pharmacologically significant thiols. Molecules. 2012; 19: 12287-96.

Heimfarth L, Loureiro SO, Reis KP, de Lima BO, Zamboni F, Gandolfi T, Narvaes R, da Rocha JBT, Pessoa-Pureur R. Cross-talk among intracellular signaling pathways mediates the diphenyl ditelluride actions on the hippocampal cytoskeleton of young rats. Chem Res Toxicol. 17, 2011; 24: 1754-64.

Heimfarth L, Loureiro SO, Dutra MF, Andrade C, Pettenuzzo L, Guma FT, Gonçalves CA, da Rocha JB, Pessoa-Pureur R. In vivo treatment with diphenyl ditelluride induces neurodegeneration in striatum of young rats: Implications of MAPK and Akt pathways. Toxicol Appl Pharmacol. 2012; 264 : 143-52 (b)

Heimfarth L, Loureiro SO, Reis KP, de Lima BO, Zamboni F, Lacerda S, Soska AK, Wild L, da Rocha JBT, Pessoa-Pureur R. Diphenyl ditelluride induces hypophosphorylation of intermediate filaments through modulation of DARPP-32-dependent pathways in cerebral cortex of young rats. Arch Toxicol. $2012 ; 86: 217-30$. (a)

Huang X, Liu Y, Liang K, Tang Y, Liu J, Construction of the active site of gluthathione peroxidase on polymer-based nanoparticles. Biomacromolecules, 2008; 9: 1467-1473.

Jacob C, Arteel GE, Kanda T, Engman L, Sies H, Water soluble organotellurium compounds: catalytic protection against peroxynitrite and release of zinc from metallothionein. Chem Res Toxicol, 2000; 13 : 3-9

Juan M, Sandoval, Philippe L, Bernard G, Claudio C, Vasquez PBC, Tellurite-induced oxidative stress leads to cell death of murine hepatocarcinoma cells. Biometals, 2010; 23: 623-632.

Kade, I. J., \& da Rocha, J. B. T. Pharmacology of organoselenium compounds: Emphasis on puzzling mechanistic switching from their glutathione peroxidase mimic in vivo. Biokemistri, 2013; 24, 1-14.

Kade, I. J., Balogun, B. D., \& Rocha, J. B. T. In Vitro Glutathione Peroxidase Mimcry of Ebselen is Linked to its Oxidation of Critical Thiols on Key Cerebral Suphydryl Proteins-A Novel Component of its GPx-mimic Antioxidant Mechanism Emerging from its Thiol-Modulated Toxicology and Pharmacology. Chemico-biological interactions. 2013

Kanski J, Drake J, Aksenova M, Engman L, Butterfield DA, Antioxidant activity of the organotellurium compound 3-[4-(N,N-dimethylamino) benzenetellurenyl] propanesulfonic acid against oxidative stress in synaptosomal membrane systems and neuronal cultures. Brain Res. 2001; 911 : 12-21.

Maciel EN, Bolzan RC, Braga AL, Rocha JBT, Diphenyl diselenide and diphenyl ditelluride differentially affect $\delta$-aminolevulinate dehydratase from liver, kidney, and brain of mice, Journal of Biochemical and Molecular Toxicology. 2000; 14: 310-319

Mao SZ, Dong ZY, Liu JQ, Li XQ, Liu XM, Luo GM, Shen JC, Semisynthethic tellurosubtilisin with gluthathione peroxidase activity. J Am Chem Soc, 2005; 127 : 11588-11589 
McNaughton M, Engman L, Birmingham A, Powis G, Cotgreave IA, Cyclodextrin-derived diorganyl tellurides as glutathione peroxidase mimics and inhibitors of thioredoxin reductase and cancer cell growth. J Med Chem, 2004; 47: 233-239

Meinerz DF, Sudati JH, Santos DB, Frediani A, Alberto EE, Allebrandt J, Franco JL, Barbosa NBV, Aschner M, Rocha JBT, Evaluation of the biological effects of (S)-dimethyl 2-(3-(phenyltellanyl) propanamido) succinate, a new telluroamino acid derivative of aspartic acid. Achieves of Toxicology. $2011 ; 8543-49$

Mischell BB, Shiingi SM, Selected Methods in Cellular Immunology. W.H. Freeman Company, New York, pp. 1980; 1-469.

Moretto MB, Boff B, Franco J, Posser T, Roessler TM, Souza DO, Nogueira CW, Wofchuk S, Rocha JBT, $\mathrm{Ca}(2 \mathrm{p})$ influx in rat brain: effect of diorganylchalcogenides compounds. Toxicol. Sci., 2007; 99: $566-571$.

Nogueira CW, Meotti FC, Curte E, Pilissão C, Zeni G, Rocha JBT. Investigations into the potential neurotoxicity induced by diselenides in mice and rats. Toxicology, 2003, 183: 29-37.

Nogueira CW, Rocha JBT, Toxicology and pharmacology of selenium: emphasis onsynthetic organoselenium compounds. Arch Toxicol. 2011; 85 : 1313-59.

Nogueira CW, Zen G, Rocha JBT, Organoselenium and organotellurium compounds: toxicology and pharmacology. Chem. Rev, 2004 104: 6255-6285.

Rigobello MP, Gandin V, Folda A, Rundlo AK, Fernandes FAP, Bindoli A, Marzano C, Bjornstedt M, Treatment of human cancer cells with selenite or tellurite in combination with auranofin enhances cell death due to redox shift. Free Radic Biol Med, 2009; 47: 710-721

Rocha JBT, Saraiva RA, Garcia SA, Gravina F, Nogueira CW, Aminolevulinate dehydratase ( $\delta$-ALA-D) as marker protein of intoxication with metals and other pro-oxidant situations. Toxicology Research, 2012; 85-102

Rosa RM, Hoch NC, Furtado GV, Saffi J, Henriques JAP, DNA damage in tissues and organs of mice treated with diphenyl diselenide. Mutation Research. 2007; $633: 35-45$.

Sailer BL, Liles N, Dickerson S, Sumners S, Chasteen TG, Organotellurium compound toxicity in a promyelocytic cell line compared to non-tellurium-containing organic analogue. Toxicol In Vitro, 2004; $18: 475-482$

Santos DB, Schiar VPP, Paixão MW, Meinerz DF, Nogueira CW, Aschner M, Rocha JBT, Barbosa NBV, Hemolytic and genotoxic evaluation of organochalcogens in human blood cells in vitroToxicology in Vitro, 2009; 23: 1195-1204. (a)

Santos DB, Schiar VPP, Ribeiro MCP, Schwab RS, Meinerz DF, Allebrandt J, Rocha JBT, Nogueira CW, Aschner M, Barbosa NBV, Genotoxicity of organoselenium compounds in human leukocytes in vitro. Mutation Research, 2009; 676: 21-26. (b)

Savegnago L, Jesse CR, Pinto LG, Rocha JB, Nogueira CW. Diphenyl diselenide attenuates acute thermal hyperalgesia and persistent inflammatory and neuropathic pain behavior in mice. Brain Res. 2007; 1175: 54-9. 
Savegnago L, Jesse CR, Santos AR, Rocha JB, Nogueira CW. Mechanisms involved in the antinociceptive effect caused by diphenyl diselenide in the formalin test. J Pharm Pharmacol. 2008; 60(12):1679-86.

Savegnago L, Pinto LG, Jesse CR, Rocha JB, Nogueira CW, Zeni G. Spinal mechanisms of antinociceptive action caused by diphenyl diselenide. Brain Res. 2007; 1162:32-7.

Savegnago L, Trevisan M, Alves D, Rocha JB, Nogueira CW, Zeni G. Antisecretory and antiulcer effects of diphenyl diselenide. Environ Toxicol Pharmacol. 2006; 21(1):86-92.

Schiar VPP, Santos DB, Paixão MW, Nogueira CW, Rocha JBT, Zeni G, Human erythrocyte hemolysis induced by selenium and tellurium compounds increased by GSH or glucose: a possible involvement of reactive oxygen species. Chemico-Biological Interactions, 2009; 177: 28-33.

Stangherlin EC, Rocha JBT, Nogueira CW, Diphenyl ditelluride impairs short term memory and alters neurochemical parameters in young rats. Pharmacol. Biochem. Behav, 2009; 91: 430-435.

Taylor,A. Biochemistry of Tellurium. Biological Trace Element Research, 1996; 55 : 231-239 